\title{
Effectiveness of a Hybrid Project-Based Learning (H-PBL) Approach for Students' Knowledge Gain and Satisfaction in a Plant Tissue Culture Course
}

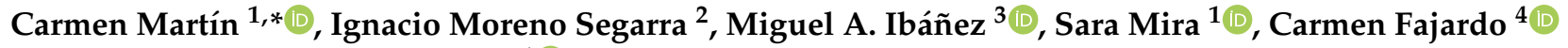 \\ and Maria Elena González-Benito ${ }^{1}$ (D)
}

check for updates

Citation: Martín, C.; Moreno Segarra, I.; Ibáñez, M.A.; Mira, S.; Fajardo, C.;

González-Benito, M.E.

Effectiveness of a Hybrid

Project-Based Learning (H-PBL)

Approach for Students' Knowledge Gain and Satisfaction in a Plant Tissue Culture Course. Educ. Sci. 2021, 11, 335. https://doi.org/ 10.3390/educsci11070335

Academic Editor: Eila Jeronen

Received: 9 June 2021

Accepted: 28 June 2021

Published: 6 July 2021

Publisher's Note: MDPI stays neutral with regard to jurisdictional claims in published maps and institutional affiliations.

Copyright: (C) 2021 by the authors. Licensee MDPI, Basel, Switzerland. This article is an open access article distributed under the terms and conditions of the Creative Commons Attribution (CC BY) license (https:// creativecommons.org/licenses/by/ $4.0 /)$.
1 Department of Biotechnology-Plant Biology, Universidad Politécnica de Madrid (UPM), 28040 Madrid, Spain; sara.mira@upm.es (S.M.); me.gonzalezbenito@upm.es (M.E.G.-B.)

2 Department of Journalism and New Media, Facultad de Ciencias de la Información, Universidad Complutense de Madrid (UCM), 28040 Madrid, Spain; igmore01@ucm.es

3 Department of Agricultural Economics, Statistics and Business Management, Universidad Politécnica de Madrid (UPM), 28040 Madrid, Spain; miguel.ibanez@upm.es

4 Department of Biomedicine and Biotechnology, Universidad de Alcalá de Henares (UAH), 28801 Alcalá de Henares, Spain; carmen.fajardo@uah.es

* Correspondence: mariacarmen.martin@upm.es

\begin{abstract}
The main objective of the present study was to evaluate the effectiveness of two learning methodologies in a Plant Tissue Culture course of a Biotechnology degree-lecture-based and hybrid project-based learning - in which a project assignment was included. The effectiveness of these two systems was compared based on the students' knowledge acquisition and the perception of their satisfaction. In this study, we evaluated the scores obtained by students in a written exam and the results of a satisfaction survey. The assessment showed that students attained improved marks in the written exam after being taught using the hybrid method. The incorporation of the project assignment in the Plant Tissue Culture program also improved the general perception that the students had of the course. The project assignment allowed the students to achieve new learning outcomes directly related to experimental work and the scientific method. The teachers perceived the hybrid project-based learning method positively, as students not only improved their knowledge gain, but were also more involved in the course.
\end{abstract}

Keywords: project-based learning; plant tissue culture; undergraduate students; students' satisfaction

\section{Introduction}

Learning is a dynamic process in which many variables influence the final results. Thus, the importance of student and teacher attitudes toward the learning environment, their external and internal motivation, and, finally, their expectations may positively or negatively determine the final learning outcomes [1]. Teaching involves different activities to achieve the intended learning outcomes, all providing students with an integral and continuous view of the subject. Theoretical lessons taught by a teacher are prominent in a lecture-based learning approach, while a student-centered learning method may include more active tasks, such as designing projects and practical activities and conducting group work and discussion sessions, among others. Pedagogies focused on student learning processes have been present within the different teaching degrees since the beginning of the 20th century [2,3]. This long tradition was renewed in the 1980s in various subjects, such as North American and, later, European medical schools [4,5], which implemented a series of measures that transformed the role of teaching staff from providers of information to facilitators of learning. This renewal of teaching based on a range of techniques aimed at highlighting learning as an active, cooperative, and inductive process has been generically called student-centered learning [6,7]. More recently, since the creation of the European 
Higher Education Area in 1999, recommendations have been made in European higher education institutions to decrease the number of credits based on the more traditional lecture-based learning approach (i.e., theoretical lessons) and to increase the acquisition of the required skills through activities that are not on-site classes, and through studentcentered learning [8,9]. Additionally, it has been suggested that teachers' strategies must change, and their traditional roles as directors of instructions must shift toward a more participatory intervention that promotes autonomy among students [10].

Moreover, in the last decade, research-led teaching has attracted increasing attention as the link between teaching and research in higher education has been highlighted [11]. The nexus between research productivity and teaching quality within university education is a complex issue that has been extensively analyzed, but often with contradictory results [11-14]. This process is leading to a profound change in contemporary universities and, therefore, cannot be reduced to having researchers teach [14].

The different approaches that appear under the conceptual umbrella of studentcentered learning may be related if we conceive of learning as a continuous process of knowledge construction focused on student motivation and underlining their autonomy and sense of competence. Project-based learning (PBL) is one of these approaches, in use since the 1990s; it is defined as a comprehensive approach to classroom teaching and learning designed to engage students in the investigation of authentic problems [15]. For these authors, activities can be organized around significant questions, linked to real problems that are solved by different groups of students over a long period of weeks or months, during which students plan an investigation, debate ideas, collect data, make predictions, and communicate their findings. A significant element of this methodology is the existence of a final goal that is present from the start [16], and an emphasis on cooperation between students who lead and control the process, and acquire the autonomy to investigate $[17,18]$. PBL is an approach to instruction that teaches curriculum concepts through a project [19]. This learning method allows students to improve their ability to learn effectively in a responsible and autonomous manner, and encourages their motivation to learn, improving general and specific competencies [20], through activities that encourage hands-on experience and the search for information from various sources [21]. This method is based on creating groups of five to eight students that handle the different parts of a complex investigation [22]. Three different phases can be identified: during the first phase, the tutor poses to the students a complex problem that cannot be solved solely with the knowledge provided in class; this problem is usually related to a practical investigation regarding a real phenomenon and lacking a single solution. During the second phase, the students guide themselves in the resolution process, collectively but also individually, identifying the kind of knowledge they lack in order to solve the problem and how they can acquire it. Finally, during the third phase, the group synthesizes, presents, and summarizes its findings.

Student-centered learning may be, according to Queen [23], especially useful in academic instruction related to research and laboratories since, due to its traditionally practical nature, it forces students to interact with each other while they investigate a phenomenon with the guidance of the teaching staff, who explain the main concepts and the methods to be applied. As this author points out, in recent years, methods have been implemented in which teachers do not assume such an active role, nor do they provide a detailed explanation of the phenomenon. This approach allows students to experience the scientific method in a manner similar to that for active research in the field, although the main challenge is the difficulty of applying this methodology during the first years of scientific university education [23].

The education provided in competitive universities has tended to integrate research productivity and teaching quality through the transmission of standards and values for scientific research, the application of new pedagogies, or the involvement of students in different research activities [24]. PBL allows students to acquire key knowledge and skills through the development of projects that respond to real-life problems [9]. The objective is 
to enhance students' autonomy, since they become the main actors in their own learning processes, and the role of the teachers is to provide guidance and support to the students throughout the entire project [18]. Within this framework, PBL is particularly attractive for students whose sought professions are based on scientific activity, as it offers them the opportunity to experience a scenario similar to that in their potential future job.

Several experiences with PBL implementation have been reported, describing the advantages of its application compared to that of more traditional learning methodologies. However, certain problems or qualms regarding its application have also been identified. Carrió et al. [25] suggested that the introduction of PBL in a Biology bachelor degree (Universitat Pompeu Fabra, Barcelona, Spain) promoted the development of students' generic and scientific skills, without detriment to knowledge acquisition, thus refuting the doubts raised by some teachers in this regard. Although, in some cases, students reported a number of disadvantages, such as limitations related to time management and laboratory conditions [26], most of the problems described in PBL implementation are related to teachers' perceptions and needs. In general, for all types of disciplines, the main difficulties with PBL implementation are related to the reluctance of teachers regarding a reduction in theoretical classes and the challenge of individual student evaluations [27]. Furthermore, difficulties have also been found in the organization of collaborative learning [28] and the lack of training and experience in implementing PBL, which have been accompanied by decreased motivation [29]. These limitations are, in many cases, related to insufficient financial and technical support [29]. Nevertheless, the advantages described outweigh the disadvantages mentioned, and most studies have pointed out the capability of students to acquire cognitive skills and significant abilities while enhancing their learning outcomes $[29,30]$. Resolving the problems described in the application of PBL requires greater efforts from students and, particularly, teachers, but this effort is worthwhile considering the benefits in the learning process observed [31].

In particular, in Plant Biotechnology studies, which is a largely dynamic area, autonomous and capable professionals who are able to address the new and demanding challenges facing this discipline must be trained. Students must acquire competencies that allow them to be autonomous and capable, and to develop skills to meet new demands. Plant cell and tissue culture is a key theoretical and practical subject with important biotechnological applications, from genetic engineering to plant propagation and from endangered plant conservation to crop phytopathology assessment. In vitro plant culture disciplines are included in a large number of bachelor and master degrees related to biotechnology topics, e.g., biology, biotechnology, agriculture, and environmental engineering degrees. However, the acquisition of competency in cellular culture techniques required in a professional biotechnology career is a challenge for most higher education programs due to its complexity and multidisciplinary aspects. Students require theoretical knowledge of cell biology and physiology, together with practical skills in highly specialized laboratory techniques, such as working in sterile conditions, which poses logistical and methodological challenges. All these requirements suggest the need for an approach to problem solving and integrating interdisciplinary education [32].

In this study, a project-based assignment was included in a "Plant Tissue Culture" course (hybrid project-based learning, H-PBL), including the development of experimental projects assigned to students; it allowed increasing training in practical research activities while decreasing the time for lectures. We compared this methodology with the lecturebased learning approach previously used. With the present study, we aimed to answer the following question: "Can hybrid project-based learning improve the effectiveness of learning in 'Plant Tissue Culture'?".

In order to address this question, the following points were evaluated:

1. Examination results, as a standardized assessment of knowledge gain.

2. Student satisfaction surveys, in order to accurately measure the extent to which the courses fulfilled their objectives.

3. The acquisition of new defined learning outcomes. 


\section{Materials and Methods}

\subsection{Study Design}

The Biotechnology bachelor degree offered by Universidad Politécnica de Madrid (UPM) is within the European Higher Education Area (EHEA) formally introduced by the Bologna Declaration. This degree is four years long (240 European Credit Transfer System, ECTS). "Cell Culture" is a mandatory course in the third year of the degree; its 6 ECTS are split across two sections-"Plant Tissue Culture" and "Animal Cell Culture"-with half of the teaching hours for each part ( $36 \mathrm{~h})$ and the final grade obtained as a mean of both parts.

The study reported here refers to the "Plant Tissue Culture" part, whose main learning outcomes (LO) are:

LO 1. To understand the principles and methods of plant tissue culture.

LO 2. To understand the use of plant cell and tissue culture techniques for biotechnological applications.

LO 3. To practice safe and sterile work procedures, applying in vitro techniques in the laboratory.

In the H-PBL methodology applied, a project assignment was included, and the following learning outcomes were also considered:

LO 4. Applying the scientific method to solve problems effectively and creatively. In addition, being able to carry out experiments and/or design applications independently and describe, quantify, analyze and critically evaluate the results obtained.

LO 5. The ability to communicate in Spanish and/or English orally and in writing.

LO 6. The ability to search for, obtain and interpret information from the main bibliographic and biological databases, and to elaborate information from experimental data.

During four consecutive academic years (from 2013-2014 to 2016-2017), the course was mainly taught through lecture-based learning, with complementary laboratory and seminar sessions. In the following three academic years (2017-2018 to 2019-2020), a projectbased assignment was implemented as part of the study program. The percentages of the instructional methods used (on-site classroom/laboratory hours) for each methodology are represented in Figure 1. The number of students was 80-100 every year, and the course was taught by the same teachers.

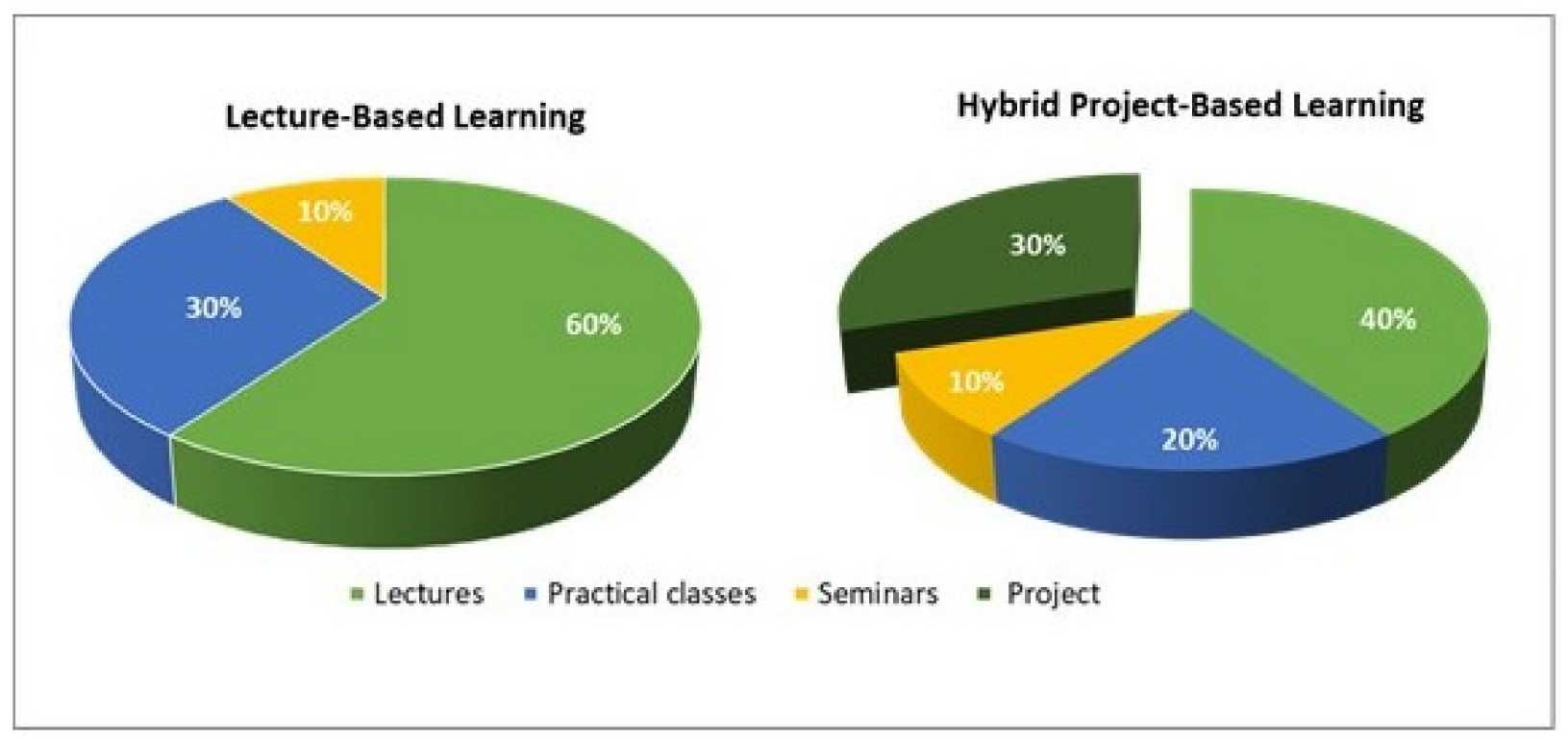

Figure 1. Percentages of hours (on-site classroom/laboratory) for instructional methods used in the lecture-based and hybrid project-based learning methodologies.

In the years in which learning was mainly based on lecture classes $(60 \%$ of the program), there were also laboratory sessions (practical classes) in which students learned 
basic skills and procedures as directed by the teacher: in these, all the students carried out the same protocols. There were also seminar sessions (10\% of the timetable) in which research papers, read by the students, were discussed in the group under the supervision of the teacher.

In the years in which the project assignment was included, the instructional tools previously used were maintained, although reducing the time for lecture classes to $40 \%$, and practical sessions to $20 \%$, keeping only those necessary for acquiring the basic skills needed to work in a plant tissue culture laboratory (see Figure 1). The addition of a project-based assignment aimed to provide students with the challenge of a real problem. This assignment focused on the following learning objectives:

1. Introducing students to autonomous experimental laboratory tasks that involved performing a particular tissue culture application.

2. Enabling students to gain knowledge on theoretical concepts through experimental work.

The project assignments were designed so that the students performed most of the tasks related to plant tissue culture techniques, from medium preparation to data recording, while resolving a real tissue culture problem. The students attended three laboratory sessions (see Figure 2 and Table 1) and subsequently followed the results during several visits to the laboratory under the supervision of the teachers. Due to the tight schedule (the course was four months long), the topic of the project assignments and the initial protocols were provided to the students. Six project assignments were designed, and the students' goal was to develop in vitro regeneration protocols. The topics and description of the assignments are shown in Table 1. The project assignments were carried out in groups of 3-4 students organized by the teachers.

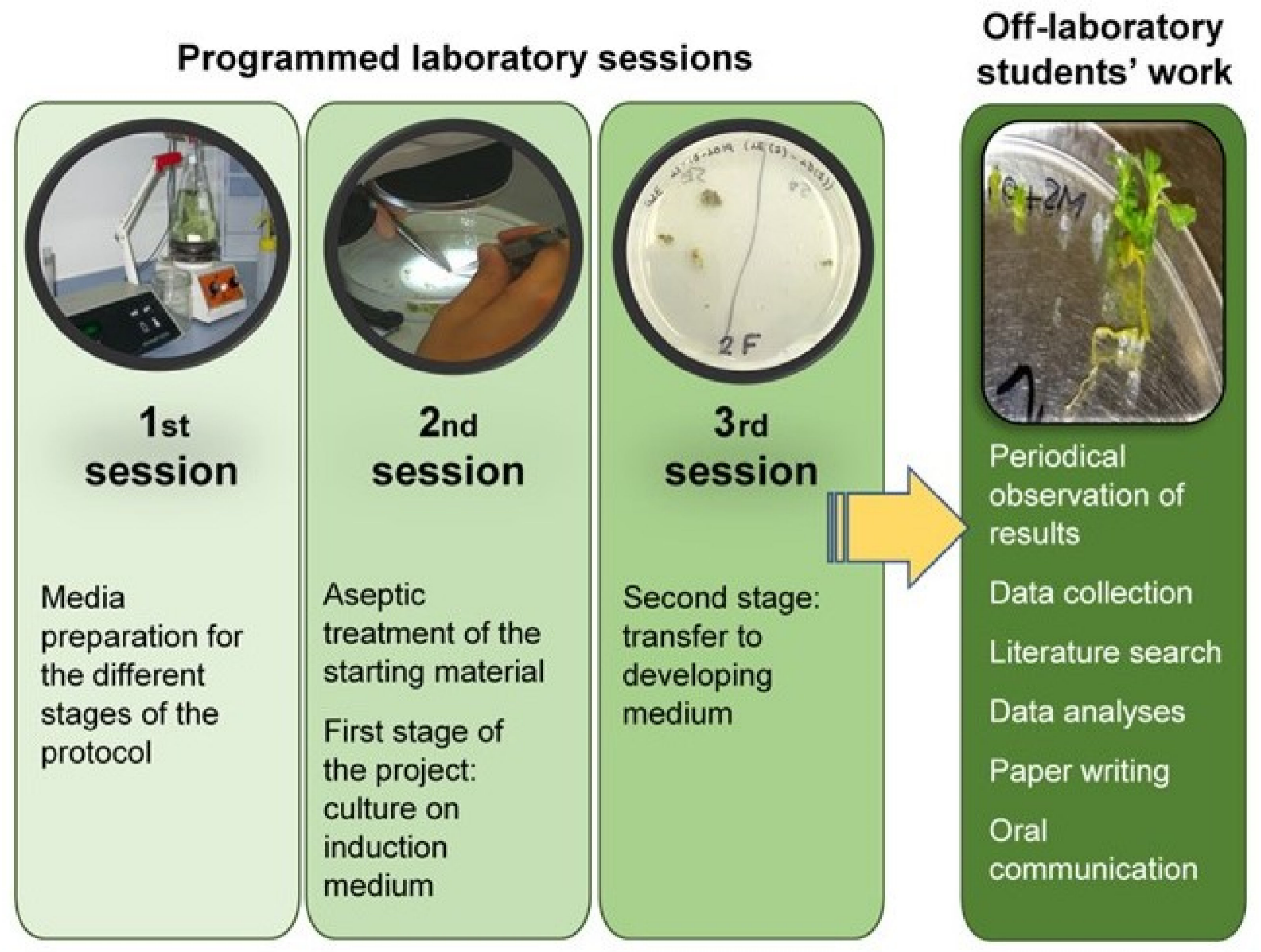

Figure 2. Plan of the experimental project sessions. 
The students had previous knowledge of searching literature and reading scientific papers from previous years, as well as oral presentations. After the laboratory sessions, the students followed the development of their experiments and collected the data in subsequent visits to the lab. With the results obtained during the experiment and information gathered through the revised scientific literature on the field of interest, each group wrote a short paper and presented the results and conclusions to their classmates and teachers. Different aspects of the development of the project assignment were considered for its evaluation, according to the achievement of the new learning outcomes (LOs) included in the hybrid methodology; each part received a different percentage of the score, as shown in Table 2. In the evaluation of the project, several elements were considered, from more formal ones, such as the written and oral presentation (LO 5), to more practical, such as laboratory skills (LO 3).

The final course scores of the students were obtained from the scores for the different instructional tools used (see Table 3). In the lecture-based learning method, the score of the written exam had more weight than in the H-PBL method. In the latter, the project assignment had a $30 \%$ weight on the final score.

\subsection{Comparing Effectiveness and Evaluating Learning Outcomes}

To determine the effectiveness of the H-PBL in the students' gain of knowledge, the scores of the written exam, similar to the one carried out in the lecture-based learning, were compared between both methods, to measure learning outcomes 1 and 2 . This exam was taken at the end of the term, and the ranges of scores considered in this analysis are shown in Table 4. According to Bedggood and Donovan [33], it is imperative to include aspects of students' satisfaction when quantifying the course's effectiveness. Therefore, we incorporated in this study the results from an anonymous standardized satisfaction survey carried out by the faculty at the end of each term for each course [34]. We compared the answers to these polls between the two learning methodologies to evaluate the degree of students' acceptance of the change in the learning method. The questions considered in the analyses for the satisfaction survey are shown in Table 5. All the answers had a maximum score of 5 points: $5=$ totally agree; $4=$ strongly agree; $3=$ agree; $2=$ disagree; $1=$ strongly disagree; 0 = totally disagree. In 2019/2020, the questions A.1, A.5 and A.7 were eliminated from the Satisfaction Survey Model of the University. For that reason, there is no information on these questions for the last academic year analyzed.

To evaluate the acquisition of the new learning outcomes through the project fulfillment, the scores obtained by the students in the projects carried out in the three consecutive years of the H-PBL methodology were analyzed. From the project's scores calculated according to the elements stated in Table 2, five score categories (similar to those used in the written exam; see Table 4) were considered.

\subsection{Statistical Analysis}

A two-way contingency table was created showing the distribution of students by exam score category and by type of learning and, in order to establish their association, a chisquare test was carried out. The satisfaction survey data were analyzed using an analysis of variance with the type of learning and the different questions as factors. The mean satisfaction score was considered the response variable.

\subsection{Teachers' Satisfaction}

The four involved teachers were interviewed at the end of the third year of the H-PBL. Prior to the start of the project, the teachers involved attended several sessions where PBL was introduced. The interviews were transcribed and subjected to a qualitative analysis. 
Table 1. Description of project assignments.

\begin{tabular}{|c|c|c|c|c|c|c|}
\hline \multirow{2}{*}{$\begin{array}{l}\text { Session/- } \\
\text { Week }\end{array}$} & \multicolumn{6}{|c|}{ Experimental Content * } \\
\hline & $\begin{array}{c}\text { Project 1. Indirect Somatic } \\
\text { Embryogenesis }\end{array}$ & $\begin{array}{l}\text { Project 2. Direct/Indirect } \\
\text { Organogenesis }\end{array}$ & $\begin{array}{l}\text { Project 3. Direct Somatic } \\
\text { Embryogenesis }\end{array}$ & Project 4. Callus Induction & Project 5. Anther Culture & Project 6. Embryo Rescue \\
\hline Goal & $\begin{array}{l}\text { Obtention of carrot somatic } \\
\text { embryos }\end{array}$ & $\begin{array}{l}\text { Shoot production in } \\
\text { chrysanthemum }\end{array}$ & $\begin{array}{l}\text { Obtention of somatic } \\
\text { embryos of melon }\end{array}$ & Callus induction in carrot & $\begin{array}{l}\text { Obtention of haploid plants } \\
\text { in chrysanthemum }\end{array}$ & $\begin{array}{l}\text { Maize zygotic embryo } \\
\text { development }\end{array}$ \\
\hline $1 / 1$ & $\begin{array}{l}\text { Medium preparation: } \\
\text { - Semi-solid MS } \\
\text { - Semi-solid MS + 0.3 2,4-D }\end{array}$ & $\begin{array}{l}\text { Medium preparation: } \\
\text { - Semi-solid MS } \\
\text { - Semi-solid MS } \\
+5 \text { BAP+ 0.1 NAA } \\
\text { - Semi-solid MS } \\
+12 \text { 2, -D + 0.25 BAP }\end{array}$ & $\begin{array}{l}\text { Medium preparation: } \\
\text { - Semi-solid MS + } 5 \text { 2,4-D + } \\
0.1 \text { TDZ } \\
\text { - Semi-solid MS + 2.3 2,4-D + } \\
0.1 \text { BAP } \\
\text { - Semi-solid MS + } 4 \text { 2,4-D + } \\
2 \text { NAA+ 0.1 BAP }\end{array}$ & $\begin{array}{l}\text { Medium preparation: } \\
\text { - Semi-solid MS in test tubes } \\
\text { (without sucrose) } \\
\text { - Semi-solid MS + } 0.1 \mathrm{kin}+0.3 \text { 2,4-D } \\
\text { - Semi-solid MS + 0.1 kin + 0.3 2,4-D }\end{array}$ & $\begin{array}{l}\text { Medium preparation: } \\
\text { - Semi-solid MS + 1.5 2,4-D + } \\
1 \text { IAA + } 2 \text { Kin } \\
\text { - Semi-solid MS + } 1 \text { 2,4-D + } \\
2 \text { BAP + 4.5\% sucrose }\end{array}$ & $\begin{array}{l}\text { Medium preparation: } \\
\text { - Semi-solid MS }+0.3 \\
\text { thiamine }+4 \% \text { sucrose } \\
\text { - MS }+0.3 \text { thiamine }+0.1 \\
\text { ABA }+4 \% \text { sucrose } \\
\text { - Semi-solid MS }+0.3 \\
\text { thiamine }+1 \text { ABA } \\
+4 \% \text { sucrose }\end{array}$ \\
\hline $2 / 2$ & $\begin{array}{l}\text { Transfer of carrot callus, of two } \\
\text { cultivars, to two different media. } \\
\text { The callus had been cultured on } \\
\text { semi-solid medium MS }+0.32,4-\mathrm{D} \\
\text { and was initiated in project } 4 \\
\text { during previous academic year. } \\
\text { Incubation: darkness. }\end{array}$ & $\begin{array}{l}\text { Surface disinfestation of leaves } \\
\text { and initiation of aseptic culture } \\
\text { of laminas and petioles of one } \\
\text { chrysanthemum cultivar on } \\
\text { three different media. } \\
\text { Incubation: darkness. }\end{array}$ & $\begin{array}{l}\text { Surface disinfestation of } \\
\text { seeds and initiation of } \\
\text { aseptic culture of zygotic } \\
\text { embryo portions (apical and } \\
\text { basal portion of cotyledons, } \\
\text { and of embryo axis) on } \\
\text { three media. } \\
\text { Incubation: darkness. }\end{array}$ & $\begin{array}{l}\text { Initiation of aseptic culture of seeds of } \\
\text { two different carrot cultivars on MS. } \\
\text { Incubation: photoperiod. }\end{array}$ & $\begin{array}{l}\text { Surface disinfestation of } \\
\text { capitula and initiation of } \\
\text { aseptic culture of anthers of } \\
\text { two different } \\
\text { chrysanthemum cultivars } \\
\text { on two media. } \\
\text { Incubation: darkness. }\end{array}$ & $\begin{array}{l}\text { Surface disinfestation of } \\
\text { maize kernels from two } \\
\text { genotypes and initiation of } \\
\text { aseptic culture of embryos } \\
\text { on three different media. } \\
\text { Incubation: photoperiod. }\end{array}$ \\
\hline$\cdots$ & $\begin{array}{l}\text { Observation: } \\
\text { - Callus morphology } \\
\text { - Number of somatic } \\
\text { embryos per callus } \\
\text { - SE in different } \\
\text { developmental stages }\end{array}$ & $\begin{array}{l}\text { Observation: } \\
\text { - Callus/shoot/root formation }\end{array}$ & $\begin{array}{l}\text { Observation: } \\
\text { - Formation of } \\
\text { somatic embryos } \\
\text { - SE in different } \\
\text { developmental stages }\end{array}$ & $\begin{array}{l}\text { Observation: } \\
\text { Callus induction }\end{array}$ & $\begin{array}{l}\text { Observation: } \\
\text { - Formation of } \\
\text { somatic embryos } \\
\text { - SE in different } \\
\text { developmental stages }\end{array}$ & $\begin{array}{l}\text { Observation: } \\
\text { - Seedling growth } \\
\text { (shoot and root length) }\end{array}$ \\
\hline
\end{tabular}

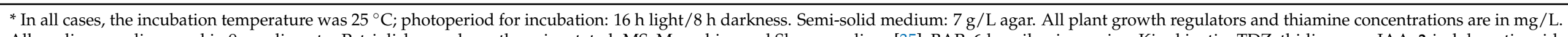

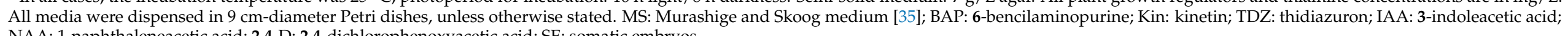
NAA: 1-naphthaleneacetic acid; 2,4-D: 2,4-dichlorophenoxyacetic acid; SE: somatic embryos. 
Table 2. Evaluation of project assignment and relationship with learning outcomes (see text).

\begin{tabular}{lcc}
\hline Project Assignment Performance Evaluation & Score Percentage & Learning Outcome(s) \\
\hline Laboratory skills & $20 \%$ & LO 3 \\
Data presentation, analysis and interpretation & $30 \%$ & LO 4 \\
Conclusions & $20 \%$ & LOs 1, 2 and 4 \\
Bibliographic review & $15 \%$ & LO 6 \\
Redaction and oral exposition & $15 \%$ & LO 5 \\
\hline
\end{tabular}

Table 3. Weights of the different evaluation items in the students' final marks in the two learning methodologies studied.

\begin{tabular}{lccc}
\hline \multicolumn{1}{c}{ Evaluation Item } & Lecture-Based Learning & Hybrid Project-Based Learning & Learning Outcome(s) Evaluated \\
\hline Written exam & $70 \%$ & $50 \%$ & LOs 1 and 2 \\
Practical sessions & $20 \%$ & $10 \%$ & LO 3 \\
Seminars & $10 \%$ & $10 \%$ & LOs 1 and 2 \\
Project assignment & - & $30 \%$ & LOs 1-6 \\
\hline
\end{tabular}

Table 4. Ranges of exam scores.

\begin{tabular}{ccl}
\hline Category & $\begin{array}{c}\text { Examination Scores } \\
\mathbf{( 0 - 1 0 ;} \mathbf{5} \geq \mathbf{P a s s})\end{array}$ & \multicolumn{1}{c}{ Degree of Acquisition of Learning Outcomes $\mathbf{1}$ and $\mathbf{2}$} \\
\hline F2 & $0.0-3.4$ & $\begin{array}{l}\text { Lack of knowledge on basic tissue culture techniques and their } \\
\text { biotechnological applications. }\end{array}$ \\
\hline F1 & $3.5-4.9$ & $\begin{array}{l}\text { Important gaps in the knowledge of tissue culture techniques and applications. } \\
\text { C }\end{array}$ \\
\hline B & $5.0-6.4$ & $\begin{array}{l}\text { Basic knowledge of in vitro culture techniques with scarce knowledge of } \\
\text { biotechnological applications. }\end{array}$ \\
\hline A & $6.5-8.4$ & $\begin{array}{l}\text { Good level of in vitro culture techniques and biotechnological applications, but with } \\
\text { small misinterpretations. }\end{array}$ \\
\hline
\end{tabular}

Table 5. Questions of the satisfaction surveys completed by the students.

\begin{tabular}{cl}
\hline Question No. & \multicolumn{1}{c}{ Question } \\
\hline A.1 & $\begin{array}{l}\text { The planned tasks (technical, practical, individual work, group work, etc.) are } \\
\text { related to what is intended to be learned in the teaching activity. }\end{array}$ \\
\hline A.2 & $\begin{array}{l}\text { In the development of this teaching activity, there are no overlaps with the } \\
\text { contents of other activities or unnecessary repetitions. }\end{array}$ \\
\hline A.3 & $\begin{array}{l}\text { The theoretical and practical tasks foreseen in the program have been } \\
\text { adequately coordinated. }\end{array}$ \\
A.4 & $\begin{array}{l}\text { The volume of content and tasks that the teaching activity comprises is } \\
\text { proportional to the credits assigned. }\end{array}$ \\
\hline A.5 & $\begin{array}{l}\text { The dedication required by this teaching activity corresponds to that foreseen } \\
\text { in the program. }\end{array}$ \\
\hline A.6 & $\begin{array}{l}\text { The way it is evaluated (exams, practical reports, individual or group } \\
\text { assignments, etc.) is related to the type of tasks (theoretical, practical, } \\
\text { individual, group, etc.) carried out. }\end{array}$ \\
\hline A.7 & $\begin{array}{l}\text { I have improved my competencies' levels, according to those of } \\
\text { the subject program. }\end{array}$ \\
\hline
\end{tabular}

\section{Results}

\subsection{Comparison of Examination Scores}

The written exam was intended to evaluate the learning outcomes 1 and 2 through questions testing the acquisition of knowledge on plant in vitro culture techniques and 
their biotechnological applications. The distribution of the mean exam scores for each learning methodology is shown in Figure 3a. The introduction of project assignments in the 2017/2018-2019/2020 academic years significantly increased the percentage of students with the highest scores and reduced the percentages in the fail categories, F1 and F2 $(p<0.001)$. In particular, an increase in scores corresponding to the highest category, $\mathrm{A}$, and a decrease in the intermediate category, $\mathrm{C}$, were observed. The mean percentage of failed scores during the years with lecture-based methodology was $9.6 \%$, and this was reduced to $4.9 \%$ in the years when the project assignment was introduced. The percentage of students with high acquisition of learning outcomes 1 and 2, corresponding to the A and B score groups (above 6.5), increased from $70.8 \%$ with the lecture-based learning method to $83.2 \%$ with the H-PBL method. A shift to higher scores was the tendency observed for the H-PBL method, as shown in Figure 3b.

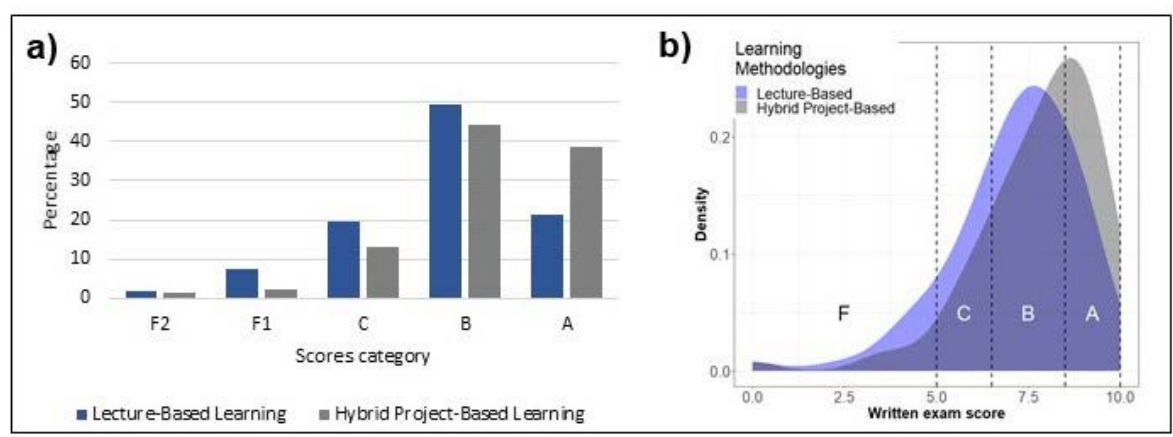

Figure 3. (a) Percentages of final scores for written exam with the two learning methodologies: lecture-based and H-PBL (numerical scores according to Table 4). (b) Score distribution for the written exam with the two learning methodologies.

\subsection{Satisfaction Survey}

The scores obtained for the different questions related to the course organization and satisfaction of the students were higher than 2.5 (over 5) in all the academic years except in 2014/2015, corresponding to the lecture-based methodology (see Figure 4). Except for this year, the satisfaction of the students was satisfactory according to all the questions, although there was a significant increase in scores from the introduction of the project assignment in the academic year 2017-2018.

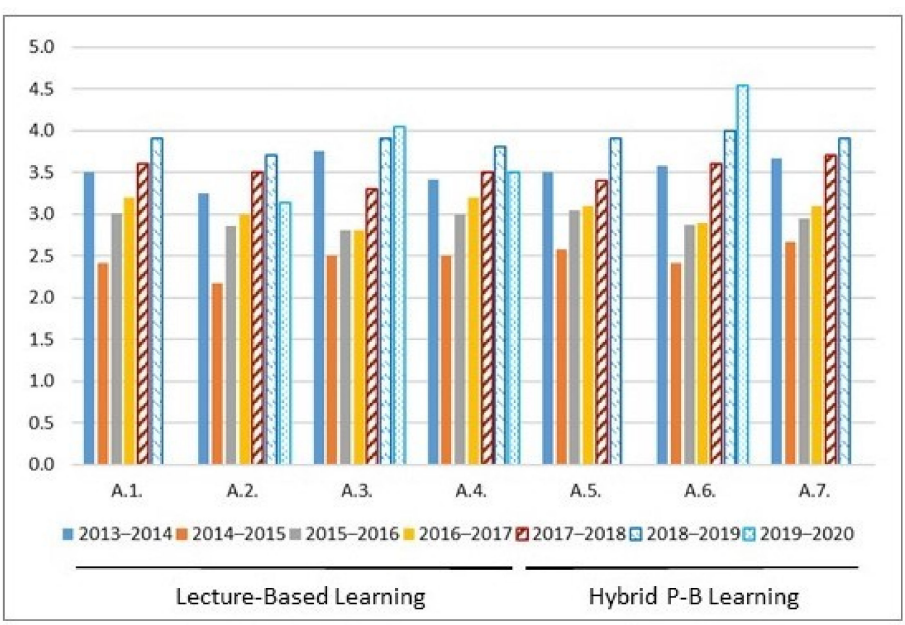

Figure 4. Scores for the satisfaction survey questions (question texts are shown in Table 5) for each academic year. 
When comparing the mean satisfaction survey scores for the two methodologies studied in this work, a clear increase was observed for all the questions after the introduction of the project assignment, as shown in Figure 5. The analysis of variance showed a significant effect of the type of learning factor, but not of the question factor and the interaction between them (see Table 6). The estimated difference in the mean satisfaction score between the H-PBL and the lecture-based learning was $0.73 \pm 0.126(p<0.001)$.

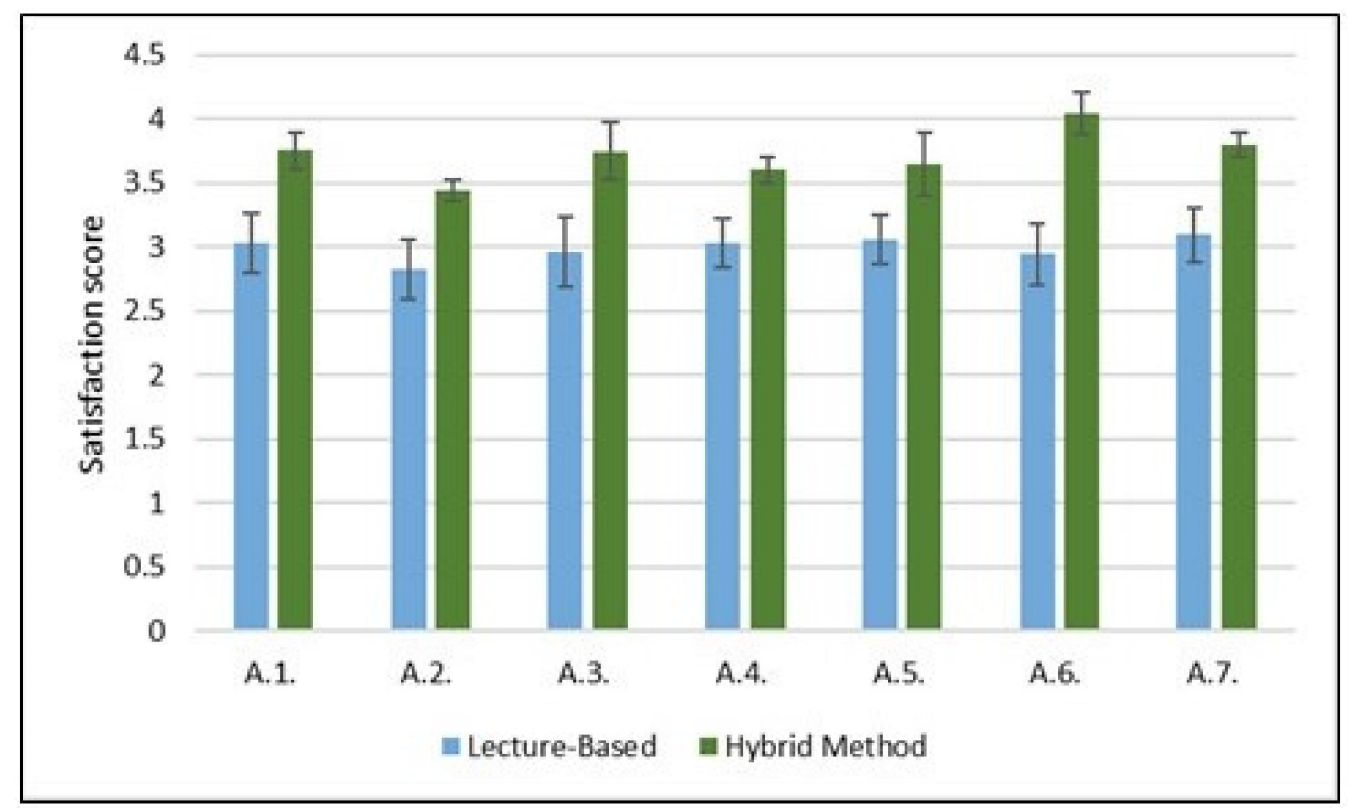

Figure 5. Mean values for the satisfaction survey questions (question texts are shown in Table 5) for each of the two learning models used. Bars: standard deviations.

Table 6. ANOVA of the mean satisfaction scores with survey questions and learning methods as factors.

\begin{tabular}{ccccc}
\hline Source of Variation & Sum Sq & Df & F Value & Pr \\
\hline Survey question & 0.4896 & 6 & 0.4799 & 0.8182 \\
Learning method & 5.8588 & 1 & 34.4618 & 0.0000 \\
Question x method & 0.3354 & 6 & 0.3288 & 0.9168 \\
Residuals & 5.4403 & 32 & & \\
\hline
\end{tabular}

Note: " $x$ " stands for interaction.

A high correlation $\left(R^{2}=0.82\right)$ between students' satisfaction and examination scores was observed for all the academic years analyzed, regardless of the learning methodology; nevertheless, that correlation was higher when considering only the data of H-PBL years $\left(R^{2}=0.99\right)$.

\subsection{Project Assignment Learning Outcomes}

The project assignment allowed the students to achieve new learning outcomes (see Table 2) directly related to experimental work and the scientific method. Over $80 \%$ of the students obtained high scores (B and A) in the evaluation of the project assignment, indicating a very satisfactory fulfillment of the learning outcomes, as shown in Figure 6. 


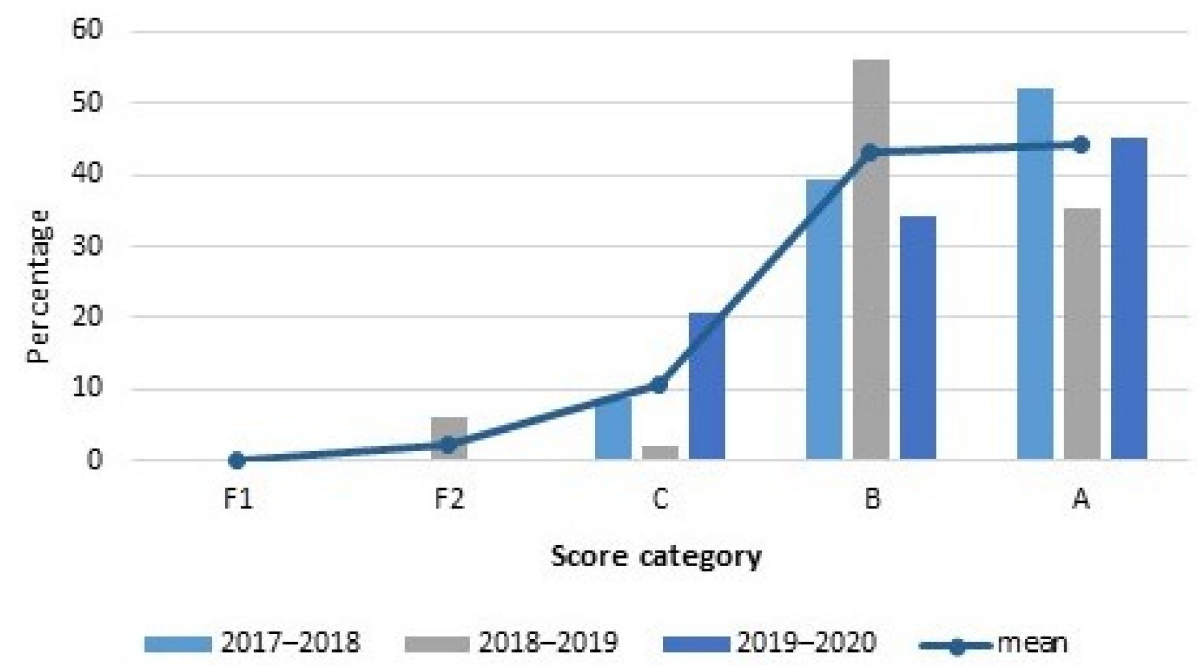

Figure 6. Percentages for the project assignment score categories during the three years and mean values.

\subsection{Teachers' Satisfaction}

The teachers' attitude towards H-PBL was positive when it was implemented, even though there were some concerns due to the high number of students.

PBL facilitates the students' control of the learning process and improves their ability to learn effectively, stimulating their motivation [20]. From a learning perspective, the answers of the teachers identified some advantages of the inclusion of the project assignment. Several teachers pointed out the following advantages (A):

- $\quad$ A: The students were more involved in the course.

- A: Deeper knowledge in some concepts of the program was obtained.

- $\quad$ A: The students better understood the process of in vitro plant culture techniques.

Some comments highlighted the following advantages:

"My experience has been generally positive. I was afraid that the students would not acquire all the knowledge as the hours dedicated to the theory classes were reduced, but this has not been the case and, in some subjects, they have been able to demonstrate deeper knowledge (Teacher 1)".

The teachers were confronted with a new way of teaching for them, where their role was more that of a facilitator than that of a knowledge provider. From the teaching perspective, the main advantages (A) and disadvantages (D) inferred from the interviews are summarized as follows:

- $\quad$ A: A more varied and enjoyable method of teaching.

- A: A closer relationship with students and their questions.

- D: More resources were required, including both teachers' time, especially during the first year, and materials.

These were some of the comments:

"The experience has meant a greater investment of time but it has served to have a greater contact with the students (Teacher 4)".

"I was concerned about the organization of the projects given the number of students per year. Although during the first year there was some difficulty in planning the projects, the following years everything flowed satisfactorily (Teacher 2)".

\section{Discussion}

The search for learning methodologies that incorporate more practical aspects and are closer to real-life tasks has been a constant in higher education over the last few decades. Traditional learning is based, almost exclusively, on lectures through which students acquire the fundamental knowledge of the subject. Although this method can be considered 
effective for delivering a large quantity of information to large groups of students, it has been criticized for failing to engage students and develop their higher-level cognitive skills [36]. It is now considered an obsolete method, with limited yields, and learning based exclusively on lectures has fallen into disuse at practically all levels of education. The inclusion of PBL as a learning methodology has been related to students' higher motivation, acquisition of much deeper learning, greater understanding, and improvement in learning effectiveness $[19,20]$. Although students acquire a different kind of knowledge with PBL, some teachers remain skeptical of the use of techniques based on collaborative work or practical classes to the detriment of lectures. Some teachers noted disadvantages with PBL in terms of the span of knowledge of the course matter acquired by the students [37].

In our study, a hybrid project-based learning method was adopted with the introduction of a project assignment in the learning program of the "Plant Tissue Culture" course. This change in the learning method had a positive effect on the acquisition of knowledge and concepts by the students, as revealed by the significant increment in high scores in the written exam. The exam scores, as a direct assessment of learning outcomes, allowed us to compare the two learning methods studied in this research (lecture-based and hybrid project-based), based on the wideness of the knowledge acquired by the students. A similar span of knowledge was gained with both methods, in contrast to the concerns expressed by some teachers [37].

Several authors support the idea that learning is strongly related to course satisfaction $[38,39]$. Our results support that finding. The incorporation of the project assignments in the program of "Plant Tissue Culture" improved the general perception that the students had of the course. All the questions included in the survey carried out by the faculty showed a significant improvement compared to the answers corresponding to the lecturebased learning years. One of the questions with a clear increment was that referring to the evaluation of the tasks carried out (A.6), which may be related to a change in attitude and motivation. Similarly, a clear improvement in the answers concerning the perception of competencies' acquisition can be observed in the results obtained for question A.7 ('Improved my competencies' levels, according to those of the subject program'). Similar results were observed in a study carried out for different courses of the Biology bachelor degree at Universitat Pompeu Fabra (Barcelona, Spain), where lecture-based learning was compared to a hybrid problem-based learning curriculum [25]. In that study, student satisfaction was greater with the PBL method. Additionally, the authors found an important enhancement of skills such as critical thinking, cooperative work, information management and communication. Contrary to our work, the authors did not find significant differences in student scores between the two educational strategies [25].

Studies at different educational levels have found that, for science subjects, student motivation and learning increase with PBL [40]. Stratford and Finkel [41] also reported that PBL promoted positive changes in the attitude towards science and the motivation for studying science. PBL has been demonstrated to have a positive impact on student learning, motivation and performance in higher education [42]. This effect can be particularly interesting in highly motivated and demanding students, for whom lecture-based learning could frustrate their expectations. Students of the Biotechnology degree of the UPM are usually very motivated and obtain high scores, as we observed in the mean values of the lecture-based learning years of "Plant Tissue Culture", when only $9.6 \%$ of the students failed the exam and $70 \%$ of the students had scores above 6.5 . The results of this study showed that highly motivated students responded positively to PBL.

Project-based strategies for teaching science subjects have also demonstrated positive effects on knowledge acquisition and critical thinking for microbiological analysis methods among undergraduate dental students [43]. In that study, there was no analysis of the scores obtained by the students in their exams, but two questionnaires for evaluating the student learning objectives were used to measure the effect of the strategy. The incorporation of a project-based assignment enables the creation of real-life experiences, which further 
stimulates the creation and development of real-life competencies [42,44]. In our research, we showed that students acquired other learning outcomes and were able to improve their communication skills and applied the scientific method.

The promotion of relevant professional skills, student autonomy, critical thinking and lifelong learning are common to student-centered learning methodologies [25]. These educational methodologies allow science students to improve their laboratory skills and abilities in scientific presentation and experiment design, as shown in an experimental program during 2012-2015 for Biochemistry students at Jilin University, China [26]. These abilities are essential for any scientific field and should be enhanced in all the educational programs. Not only is the acquisition of concepts and practical skills fundamental for learning science-related subjects, but it is also important for encouraging vocational students that could pursue a scientific career in the future. In this sense, it is fundamental to establish a comprehensive instructional approach to engaging students in investigation [17]. The use of PBL makes students apply the scientific method in their training, allowing students to acquire experience in a similar way to active research in the field [23], facilitating their approach to science from a professional point of view. Graduates from higher education institutions are expected to be ready to compete in the job market [42]; therefore, the acquisition of more practical learning outcomes will improve their prospects.

Based on the teachers' satisfaction interviews carried out, the authors believe that H-PBL is a valuable methodology with which to improve students' concept acquisition and motivation. The excellent results obtained by the students and the improved opinions they had of the course compensate for the effort that the teachers had to make to prepare all the different experimental projects that the students carried out. Similarly, higher motivation and enthusiasm were achieved for teachers implementing PBL in their science classrooms [45]. Nevertheless, if several courses in a degree are transformed into PBL, appropriate coordination between them is required.

The results of this study based on students' and teachers' perspectives support the effectiveness of H-PBL. This learning model can also be a good tool to help the transition from traditional models to those fundamentally based on student-centered approaches [46]. Future research in this field should consider evaluating the impact of H-PBL applied to several courses in a degree, especially those of an interdisciplinary character. For this purpose, it will be necessary to search for solutions at the institutional level, mainly focused on addressing the challenges teachers face in implementation and organization.

\section{Conclusions}

According to this research, hybrid project-based learning in science contributes to the development of scientific skills and provides a more enjoyable and motivated method of learning. Our study has demonstrated that the acquisition of theoretical concepts may be reinforced through project assignments, where the students are directly involved in the processes studied, and it allows students to experiment with real problems. Additionally, the results shown here address the concerns of teachers regarding the possibility that the theoretical bases of the course may not be adequately addressed using the PBL approaches, and at the same time, the teachers found it a more varied and enjoyable method of teaching.

Author Contributions: Conceptualization, C.M. and M.E.G.-B.; methodology, C.M., I.M.S., M.A.I., S.M., C.F. and M.E.G.-B.; formal analysis, C.M., M.A.I. and M.E.G.-B.; investigation, C.M., I.M.S., M.A.I., S.M., C.F. and M.E.G.-B.; writing-original draft preparation, C.M., I.M.S. and M.E.G.-B.; writing-review and editing, C.M., I.M.S., M.A.I., S.M., C.F. and M.E.G.-B.; funding acquisition, C.M. All authors have read and agreed to the published version of the manuscript.

Funding: This research was funded by the Innovative Education Program of the Universidad Politécnica de Madrid (Project No. IE1920.2003).

Institutional Review Board Statement: Not applicable.

Informed Consent Statement: Not applicable. 
Data Availability Statement: The data that support the findings of this study are available on request from the last author (M.E.G.-B.).

Acknowledgments: The authors thank Borja Hontañón (Education Science Department, Universidad de Alcalá de Henares) for critically proofreading the text.

Conflicts of Interest: The authors declare no conflict of interest. The funders had no role in the design of the study; in the collection, analyses, or interpretation of data; in the writing of the manuscript; or in the decision to publish the results.

\section{References}

1. Şen, H.S. The attitudes of university students towards learning. 2nd World Conference on Educational Technology Researches-WCETR2012. Procedia Soc. Behav. Sci. 2013, 83, 947-953. [CrossRef]

2. Piaget, J. The Language and Thought of the Child; Routledge: London, UK, 1959.

3. Dewey, J. Moral Principles in Education and My Pedagogic Creed; Myers Education Press: Gorham, ME, USA, 2019.

4. Savery, J. Problem-Based Learning. In Encyclopedia of Educational Reform and Dissent; Hunt, T.C., Lasley, T.J., II, Raisch, C.D., Eds.; Sage Publications: Thousand Oaks, CA, USA, 2010; pp. 723-726.

5. Savery, J. Overview of problem-based learning: Definitions and distinctions. In Essential Readings in Problem-Based Learning: Exploring and Extending the Legacy of Howard S. Barrows; Walker, A.E., Leary, H., Hmelo-Silver, C.E., Ertmer, P.A., Eds.; Purdue University Press: West Lafayette, IN, USA, 2015; pp. 5-17.

6. Hoidn, S. Student-Centered Learning Environments in Higher Education Classrooms; Springer: New York, NY, USA, 2017.

7. Hoidn, S.; Klemenčič, M. The Routledge International Handbook of Student-Centred Learning and Teaching in Higher Education; Routledge: Abingdon, UK, 2021.

8. Kelley, C.A.; Conant, J.S.; Smart, D.T. Master teaching revisited pursuing excellence from the students' perspective. J. Mark. Educ. 1991, 13, 1-10. [CrossRef]

9. Hadim, H.A.; Esche, S.K. Enhancing the engineering curriculum through project-based learning. In Proceedings of the 32nd Annual Frontiers in Education, Boston, MA, USA, 6-9 November 2002; pp. 1-6. [CrossRef]

10. Camerino, O.; Valero-Valenzuela, A.; Prat, Q.; Manzano Sánchez, D.; Castañer, M. Optimizing Education: A Mixed Methods Approach Oriented to Teaching Personal and Social Responsibility (TPSR). Front. Psychol. 2019, 10, 1439. [CrossRef]

11. Griffiths, R. Knowledge production and the research-teaching nexus: The case of the built environment disciplines. Stud. High. Educ. 2005, 29, 709-726. [CrossRef]

12. Hattie, J.; Marsh, H.W. The relationship between research and teaching: A meta-analysis. Rev. Educ. Res. 1996, 66, 507-542 [CrossRef]

13. Healey, M. Linking research and teaching to benefit student learning. J. Geogr. Higher Educ. 2005, 29, 183-201. [CrossRef]

14. Mägi, E.; Beerkens, M. Linking research and teaching: Are research-active staff members different teachers? High. Educ. 2016, 72, 241-258. [CrossRef]

15. Blumenfeld, P.C.; Soloway, E.; Marx, R.W.; Krajcik, J.S.; Guzdial, M.; Palincsar, A. Motivating project-based learning: Sustaining the doing, supporting the learning. Educ. Psychol. 1991, 26, 369-398. [CrossRef]

16. Barron, B.J.S.; Schwartz, D.L.; Vye, N.J.; Moore, A.; Petrosino, A.; Zech, L.; Bransford, J.D.; The Cognition and Technology Group at Vanderbilt. Doing with understanding: Lessons from research on problem- and project-based learning. J. Learn. Sci. 1998, 7, 271-311.

17. Shui-Fong, L. Project-Based Learning. In Encyclopedia of the Sciences of Learning; Seel, N.M., Ed.; Springer: New York, NY, USA, 2012; pp. 2707-2708.

18. Valero-Valenzuela, A.; Camerino, O.; Manzano-Sánchez, D.; Prat, Q.; Castañer, M. Enhancing Learner Motivation and Classroom Social Climate: A Mixed Methods Approach. Int. J. Environ. Res. Public Health 2020, 17, 5272. [CrossRef]

19. Bell, S. Project-based learning for the 21st century: Skills for the future. Clear. House J. Educ. Strateg. Issues Ideas 2010, 83, 39-43. [CrossRef]

20. Chang, C.-C.; Kuo, C.-G.; Chang, Y.-H. An assessment tool predicts learning effectiveness for project-based learning in enhancing education of sustainability. Sustainability 2018, 10, 3595. [CrossRef]

21. Boyle, P.; Trevitt, C. Enhancing the quality of student learning through the use of subject learning plans. High. Educ. Res. Dev. 1997, 16, 293-308. [CrossRef]

22. Chance, S.M. Problem-Based Learning: Use in engineering disciplines. In The SAGE Encyclopedia of Higher Education; David, M.E., Amey, M.J., Eds.; SAGE: Thousand Oaks, CA, USA, 2020; pp. 1198-1200.

23. Queen, A.E. Laboratory Instruction. In The SAGE Encyclopedia of Higher Education; David, M.E., Amey, M.J., Eds.; SAGE: Thousand Oaks, CA, USA, 2020; pp. 906-909.

24. Brew, A. Imperatives and challenges in integrating teaching and research. High. Educ. Res. Dev. 2010, 29, 139-150. [CrossRef]

25. Carrió, M.; Larramona, P.; Baños, J.E.; Pérez, J. The effectiveness of the hybrid problem-based learning approach in the teaching of biology: A comparison with lecture-based learning. J. Biol. Educ. 2011, 45, 229-235. [CrossRef]

26. Li, B.; Jia, X.; Chi, Y.; Liu, X.; Jia, B. Project-based learning in a collaborative group can enhance student skill and ability in the biochemical laboratory: A case study. J. Biol. Educ. 2020, 54, 404-418. [CrossRef] 
27. Delgado Trujillo, A.; de Justo Moscardó, E. Evaluación del diseño, proceso y resultados de una asignatura técnica con aprendizaje basado en problemas. [Evaluation of the design, process and results of a technical subject with problem-based learning]. Educación XX1 2018, 21, 179-203. [CrossRef]

28. Levy, D.; Dor, O. Amazed by making: How do teachers describe their PBL experience. In Proceedings of the 13th International Conference on Cognition and Exploratory Learning in Digital Age, Mannheim, Germany, 28-30 October 2016; pp. 142-148.

29. Efstratia, D. Experiential education through Project Based Learning. Procedia Soc. Behav. Sci. 2014, 152, 1256-1260. [CrossRef]

30. Lasauskiene, J.; Rauduvaite, A. Project-Based Learning at university: Teaching experiences of lecturers. Procedia Soc. Behav. Sci. 2015, 197, 788-792. [CrossRef]

31. Heuchemer, S.; Martins, E.; Szczyrba, B. Problem-Based Learning at a "Learning University": A view from the field. Interdiscip. J. Probl. Based Learn. 2020, 14. [CrossRef]

32. National Academies of Sciences, Engineering, and Medicine. Convergence: Facilitating Transdisciplinary Integration of Life Sciences, Physical Sciences, Engineering, and Beyond; The National Academies Press: Washington, DC, USA, 2014. [CrossRef]

33. Bedggood, R.E.; Donovan, J.D. University performance evaluations: What are we really measuring? Stud. High. Educ. 2012, 37, 825-842. [CrossRef]

34. Gómez, E.; Maresca, P.; Caja, J.; Barajas, C.; Berzal, M. Developing a new interactive simulation environment with Macromedia Director for teaching applied dimensional metrology. Measurement 2011, 44, 1730-1746. [CrossRef]

35. Murashige, T.; Skoog, F. A revised medium for rapid growth and bio assays with tobacco tissue cultures. Physiol. Plant. 1962, 15, 473-497. [CrossRef]

36. Gilboy, M.B.; Heinerichs, S.; Pazzaglia, G. Enhancing student engagement using the flipped classroom. J. Nutr. Educ. Behav. 2015, 47, 109-114. [CrossRef] [PubMed]

37. Abrandt Dahlgren, M.; Castensson, R.; Dahlgren, L.O. PBL from the teachers' perspective. High. Educ. 1998, 36, 437-447. [CrossRef]

38. Guolla, M. Assessing the teaching quality to student satisfaction relationship: Applied customer satisfaction research in the classroom. J. Mark. Theory Pract. 1999, 7, 87-97. [CrossRef]

39. Winberg, T.M.; Hedman, L. Student attitudes toward learning, level of pre-knowledge and instruction type in a computersimulation: Effects on flow experiences and perceived learning outcomes. Instr. Sci. 2008, 36, 269-287. [CrossRef]

40. Toolin, R.E. Striking a balance between innovation and standards: A study of teachers implementing project-based approaches to teaching science. J. Sci. Educ. Technol. 2004, 13, 179-187. [CrossRef]

41. Stratford, S.; Finkel, E. The impact of Science Ware and foundations on students' attitudes towards science and science classes. J. Sci. Educ. Technol. 1996, 5, 59-67. [CrossRef]

42. Ngereja, B.; Hussein, B.; Andersen, B. Does Project-Based Learning (PBL) Promote Student Learning? A Performance Evaluation. Educ. Sci. 2020, 10, 330. [CrossRef]

43. Veses, V.; Jovani-Sancho, M.M.; González-Martínez, R.; Cortell-Ballester, I.; Sheth, C.C. Raising awareness about microbial antibiotic resistance in undergraduate dental students: A research-based strategy for teaching non-laboratory elements of a microbiology curriculum. BMC Med. Educ. 2020, 20, 47. [CrossRef] [PubMed]

44. Guo, Y.; Yang, L.; Chen, X.; Yang, L. An engineering-problem-based short experiment project on finite element method for undergraduate students. Educ. Sci. 2020, 10, 45. [CrossRef]

45. Rosenfield, S.; Ben-Hur, Y. Project-based learning in science and technology: A case study of professional development. In Proceedings of the IOSTE Symposium in Southern Europe on Science and Technology Education: Preparing Future Citizens, Cyprus, Greece, 29 April-2 May 2001.

46. Kolmos, A. Facilitating change to a problem-based model. Int. J. Acad. Dev. 2002, 7, 64-74. [CrossRef] 